\title{
Representasi Maskulinitas Hegemonik dalam Iklan
}

\author{
Deddy Suprapto \\ Universitas Teknologi Sumbawa
}

\section{Keywords:}

masculinity;

hegemony;

patriarchy;

capitalism;

consumerism

\section{Kata kunci:}

maskulinitas;

hegemoni;

patriarki;

kapitalisme;

konsumerisme

\section{ABSTRAK}

\begin{abstract}
This research aims at observing how advertisement define hegemonic masculinity and identifying the models of hegemonic masculinity in Indonesia. This research takes and focuses on Gudang Garam's 2006-2010-released advertisements for the data. This research applies the analytical method of Fairclough's three-dimension of critical discourse analysis. First, the analysis is conducted by describing the advertisements. Then, the interpretation of the contexts of both the primary and secondary data. Finally, the explanation of the socio-cultural dimension. The results of this research shows that there are transformations on the representation of hegemonic masculinity from macho to metrosexual, which is influenced by capitalism and consumerism. The transformation is only on the physical appearance, not in its essence.
\end{abstract}

\begin{abstract}
Abstrak: Penelitian ini bertujuan untuk melihat bagaimana iklan mendefinisikan maskulinitas hegemonik dan mengidentifikasi bentuk-bentuk maskulinitas hegemonik di Indonesia. Objek yang akan dikaji adalah iklan-iklan rokok Gudang Garam yang dirilis sekitar tahun 2006 - 2010. Penelitian ini menerapkan tiga dimensi analisis wacana kritis Fairclough sebagai metode analisis. Pertama, analisis dilakukan dengan mendeskripsikan gambar iklan. Selanjutnya interpretasi kontekstual yang melibatkan data primer dan sekunder. Terakhir, eksplanasi dimensi sosiokultural. Hasil penelitian ini menunjukkan bahwa adanya pergeseran bentuk-bentuk maskulinitas hegemonik dari macho ke metroseksual, yang dipengaruhi oleh kapitalisme dan konsumerisme. Perubahan tersebut hanya pada tampilan fisiknya saja, tetapi tidak pada esensinya.
\end{abstract}

Alamat Korespondensi:

E-mail: deddysuprapto@yahoo.com (Deddy Suprapto)

\section{Pendahuluan}

Anggapan umum yang menyatakan bahwa maskulinitas lebih dominan dari femininitas hingga hari ini masih bertahan. Dalam masyarakat yang menganut sistem budaya patriarki, kaum laki-laki secara kultural maupun sosial banyak mendapatkan hak-hak istimewa (privileges) dibandingkan kaum perempuan. Realitas ini kemudian melahirkan pandangan yang menggeneralisasikan bahwa laki-laki lebih superior dan kerap melakukan penindasan terhadap perempuan. Pandangan yang paling sinis datang dari kelompok-kelompok feminis. Kelompok feminis radikal yang muncul di barat sekitar tahun 60-an secara ekstrim menganggap bahwa penindasan terhadap kaum perempuan berakar pada jenis kelamin laki-laki itu sendiri beserta ideologi patriarkinya.

Kelompok maskulinitas dominan ini, oleh R.W. Connell disebut dengan istilah hegemonic masculinity atau maskulinitas hegemonik. Connell mengatakan bahwa hegemonic masculinity is the culturally idealized form of masculine character. Sederhananya, maskulinitas hegemonik adalah bentuk-bentuk ideal seorang laki-laki yang dikonstruksi oleh masyarakat. Karena terkait masalah kultural maka bentuk-bentuk maskulinitas hegemonik ini selalu berubah-ubah dari satu tempat dengan tempat lainnya dan dari waktu ke waktu lainnya. Bentuk-bentuk tersebut dapat menjadi hegemonik ketika bentuk tersebut diterima oleh sebuah kebudayaan dan diterima oleh ideologi gender dominan dalam kebudayaan tersebut. Sebagai contoh, sekitar tahun 1980-an, bentuk fisik yang dianggap ideal dan maskulin dalam film-film Amerika adalah bentuk fisik ala Rambo (Sylvester Stallone) dan Arnold Schwarzenegger. Kemudian berubah menjadi lebih lembut dan canggih ala Brad Pitt dan George Clooney yang menjadi lebih dominan pada era 1990-an dan 2000-an. Artinya, ada pergeseran bentuk ideal yang terjadi, dari kekuatan fisik ke bentuk yang lebih mengedepankan intelektualitas. Sebagaimana yang dikatakan Charlebois, hal ini terjadi karena kedatangan globalisasi yang telah membawa bentuk baru maskulinitas hegemonik, dimana yang dominan tidak pada kekuatan fisik, 
melainkan pada intelektualitas, kemampuan berkompetisi, dan kemampuan untuk melakukan kontrol melalui kekuatan institusi sosial.

Periklanan sebagai sebuah sistem komunikasi massa, kini cenderung menjadi parameter dan implementasi wacana gender yang menggugat adanya bias-bias ketidakadilan gender (gender innequalities). Periklanan kini dengan agak sinis dikatakan sebagai sarana legitimasi hegemoni ideologi maupun pelestari dominasi ideologi patriarkis. Sehingga tidaklah berlebihan jika David Crystal mengatakan bahwa iklan adalah produk budaya yang paling kontroversial, jika dilihat dari perspektif moral, ideologi dan estetikanya. Kecenderungan menggunakan periklanan sebagai media untuk menunjukkan superioritas laki-laki memang mudah sekali dimunculkan. Hal ini disebabkan karena periklanan selalu memotret realitas sosial. Kontestasi makulinitas dan femininitas dalam budaya patriarki menjadi sasaran empuk iklan, dengan memainkan kode-kode tertentu untuk meraih simpati kelompok gender tertentu. Meski nyaris selalu bias gender namun iklan tidak perduli.

Iklan menjadi media yang paling tepat untuk melihat representasi maskulinitas hegemonik karena iklan bertujuan untuk memasarkan sebuah produk, maka secara sadar ia akan menampilkan bentuk-bentuk atau citra-citra yang sedang berlaku di masyarakat. Biasanya, iklan-iklan akan mengacu pada ideologi-ideologi yang dominan. Selama ini, iklan hampir selalu menempatkan perempuan pada posisi subordinat, sehingga akhirnya sampai pada kesimpulan bahwa laki-laki selalu mendominasi, dan telah menjadi kebenaran dalam masyarakat. Padahal sesungguhnya iklan tidak hanya menampilkan dominasi terhadap perempuan saja, tetapi terhadap laki-laki juga, atau keduanya secara bersamaan. Iklan yang akan dianalisa adalah iklan-iklan rokok Gudang Garam (selanjutnya ditulis GG) yang ditayangkan di televisi dalam rentang waktu tahun 2006-2010. Alasannya karena rokok selama ini identik dengan dunia maskulinitas dan sudah sangat akrab dengan masyarakat Indonesia. Pemilihan iklan-iklan GG dengan pertimbangan bahwa tampilan iklan-iklan GG dianggap paling sering merepresentasikan dunia maskulinitas.

Untuk itu, maka penelitian dengan topik "Representasi Maskulinitas Hegemonik dalam Iklan Rokok Gudang Garam", mencoba melihat bagaimana bentuk-bentuk maskulinitas hegemonik dengan menjawab dua pertanyaan; pertama, bagaimanakah iklan GG mendefinisikan maskulinitas hegemonik? Kedua, bagaimanakah bentuk-bentuk maskulinitas hegemonik di Indonesia yang direpresentasikan dalam iklan GG?

\section{Metode}

Data-data penelitian ini akan dianalisis menggunakan metode Analisis Wacana Kritis (Critical Discourse Analysis,CDA). Fairclough memahami CDA terkait dengan dua asumsi penggunaan bahasa: bahwa bahasa itu menyusun dan tersusun secara sosial. Ia mendasarkan gagasan ini pada teori linguistik multifungsional yang diwujudkan dalam 'lingusitik fungsional-sistemik' yang dikemukakan oleh Halliday; setiap teks memiliki fungsi 'ideasional' melalui representasi atas pengalaman dan representasi atas dunia ini. Melalui gagasan multifungsional bahasa dalam teks, Fairclough mengoperasionalkan asumsi teoritis bahwa teks dan wacana itu tersusun secara sosial. Penggunaan bahasa selalu tersusun atas; identitas sosial, relasi sosial, sistem pengetetahuan dan keyakinan.

Fairclough menandakan tiga dimensi pada setiap peristiwa diskursif yakni teks, praktik diskursif (mencakup produksi dan interpretasi teks), dan praktik sosial. Pertama, textual level, dilakukan analisis bentuk dan isi. Menurutnya, isi dan bentuk tidak dapat dipisahkan. Isi diwujudkan oleh bentuk tertentu; isi yang berbeda juga menyiratkan bentuk yang berbeda dan demikian sebaliknya. Yang dimaksud analisis linguistik suatu teks, menurut Fairclough adalah analisis fonologi, tata bahasa, kosakata, dan semantik. Kedua, level of discursive practice adalah hubungan antara teks dan praktik sosial. Praktik diskursif berkaitan dengan aspek sosio-kognitif produksi dan intepretasi teks. Di satu sisi, aspek tersebut dibentuk oleh praktik sosial dan membantu dalam pembentukannya, di sisi lain erat kaitannya dengan tataran tekstual. Oleh sebab itu, analisis praktik diskursif tidak hanya mencakup penjelasan yang tepat tentang cara partisipan menginterpretasikan dan menghasilkan teks dalam suatu interaksi, namun juga hubungan peristiwa-peristiwa diskursif dengan tatanan wacana, yang merupakan masalah interdiskursivitas. Ketiga, level of social practice, berhubungan dengan berbagai tataran organisasi sosial yang berbeda-beda: situasi, konteks institusional, konteks sosial atau kelompok yang lebih luas. Permasalahan kekuasaan menjadi tema pokok; kekuasaan dan ideologi bisa memberikan pengaruh terhadap masing-masing tataran kontekstual.

Selanjutnya Fairclough dan Wodak berpendapat bahwa analisis wacana kritis melihat wacana pemakaian bahasa dalam tuturan dan tulisan sebagai bentuk praktek social. Menggambarkan wacana sebagai praktik social menyebabkan sebuah hubungan dialektis di antara peristiwa diskursif tertentu dengan situasi, institusi, dan struktur sosial yang membentuknya. Praktik wacana bisa jadi menampilkan efek ideologi: ia dapat memproduksi dan mereproduksi hubungan kekuasaan yang tidak imbang antara kelas sosial, laki-laki dan wanita, kelompok mayoritas dan minoritas melalui mana perbedaan itu direpresentasikan dalam posisi social yang ditampilkan. Melalui wacana, sebagai 
contoh, keadaan yang rasis, seksis, atau ketimpangan dari kehidupan sosial dipandang sebagai sesuatu yang common sense, suatu kewajaran? alamiah, dan memang seperti itu kenyataannya. Analisis wacana kritis melihat bahasa sebagai faktor penting, yakni bagaimana bahasa digunakan untuk melihat ketimpangan kekuasaan dalam masyarakat terjadi. Analisis wacana kritis menyelidiki bagaimana melalui bahasa kelompok sosial yang ada saling bertarung dan mengajukan versinya masing-masing. Untuk itu, iklan-iklan rokok yang juga memiliki fungsi ideasional akan di analisis dengan menggunakan tiga pendekatan CDA dari Norman Fairclough. Dengan harapan dapat mengurai kompleksitas maskulin dalam iklan-iklan tersebut, sekaligus juga menemukan ideologi yang terkandung di dalamnya.

\section{Hasil dan Pembahasan}

Iklan-iklan GG yang dianalisis adalah iklan-iklan yang dianggap paling merepresentasikan maskulinitas. Iklaniklan tersebut antara lain iklan Surya Pro versi Capoera, yang dirilis Januari 2007, iklan GG versi Book Store yang dirilis Mei 2009, iklan GG versi The Plane yang dirilis Juli 2009, dan iklan Surya 12 Premium versi The Bag yang dirilis Maret 2010. Berdasarkan hasil analisis data-data iklan produk rokok GG, ditemukan beberapa hal yang sangat dominan dan dipastikan hampir selalu hadir dalam setiap representasi laki-laki dalam iklan-iklan GG, yaitu hal-hal yang bersifat fisik dan kepribadian serta materi.

\section{Fisik dan Kepribadian}

Faktor jasmani dan rohani memiliki peran signifikan ketika berbicara persoalan dominan atau dominasi, karena kedua faktor tersebut akan mempengaruhi hal-hal lainnya. Misalnya bentuk tubuh dan kepribadian seseorang akan mempengaruhi jenis aktivitas pekerjaannya, dan pekerjaan sangat mempengaruhi pencapaian kekayaan seseorang, dan kelak kesemuanya akan berpengaruh pada bentuk relasi laki-laki dengan wanita. Tubuh dan kepribadian adalah sesuatu yang tidak bisa terpisahkan.

Kepribadian meliputi aspek jasmaniah dan rohaniah. Kepribadian adalah suatu sistem psikofisik, yaitu suatu kesatuan antara aspek-aspek fisik dengan psikis. Kepribadian bukan hanya terdiri atas aspek fisik, juga bukan hanya terdiri atas aspek psikis, tetapi keduanya membentuk satu kesatuan. Kalau individu berjalan, maka yang berjalan bukan hanya dengan kakinya tetapi dengan seluruh aspek keperibadiannya. Bukan kaki yang berjalan tetapi individu. Demikian juga kalau individu berbicara, berpikir, melamun dsb, yang melakukan semua perbuatan itu adalah individu. Kretschmer, seorang ahli penyakit jiwa berkebangsaan Jerman. Ia menunjukkanadanya hubungan yang erat antara tipetipe tubuh seseorang dengan sifat-sifat dan wataknya. Ia membagi manusia dalam 4 golongan menurut tipe tubuhnya, yaitu: 1) Atletis: tinggi, besar, otot kuat, kekar dan tegap, dada lebar. 2) Astenis: tinggi, kurus, tidak kuat, bahu sempit, lengan dan kaki kecil. 3) Piknis: bulat, gemuk, pendek, muka bulat, leher pejal. 4) Displastis: merupakan bentuk tubuh campuran dari ketiga tipe sebelumnya.

Melalui bentuk fisik seseorang, maka secara umum kita bisa menebak sifat-sifatnya. Menurut Kretschmer, orang yang berbentuk tubuh atletis dan astenis tipe wataknya disebut schizothim, yang mempunyai sifat-sifat antara lain: sukar bergaul, mempunyai kebiasan yang tetap, sukar menyesuaikan diri dengan situasi-situasi yang baru, kelihatan sombong, egoistis dan bersifat ingin berkuasa, kadang-kadang optimis dan kadang-kadang pesimis, selalu berpikir dahulu sebelum bertindak. Sedangkan orang yang berbentuk tubuh piknis tipe wataknya disebut siklothim, dan mempunyai sifat-sifat antara lain: mudah bergaul, suka humor, mudah berubah-ubah stemming-nya, mudah menyesuaikan diri dengan sesuatu yang baru, kurang setia dan tidak konsekuen, lekas memaafkan kesalahan orang lain.

Heymauns, seorang ahli psikologi berkebangsaan Belanda, membagi watak manusia berdasarkan sifat-sifat psikis yang menurutnya merupakan sifat-sifat pokok dari jiwa manusia. Sifat tersebut adalah emosionalitas, aktifitas dan sekunder-fungsi (proses pengiring). Dengan melakukan penelitian terhadap biografi orang-orang besar dunia dari berbagai rentang zaman, ia membagi ketiga sifat psikis di atas menjadi 8 tipe, yaitu: 1) Gepassioneer (berpassi), bersifat revolusioner dan hebat segalanya. 2) Kholerikus, bersifat garang dan agresif. 3) Sentimentil, bersifat lekas merayu dan perasa. 4) Nervous, bersifat gugup, mudah tersinggung, bingung. 5) Flegmatikus, bersifat tenang, tidak mudah berubahubah. 6) Sanguinikus, bersifat gembira, lincah, optimis. 7) Apath, bersifat apatis, manusia mesin. 8) Amorph, bersifat tidak berperangai, lemah, lembek.

Ciri khas yang paling menonjol dalam iklan-iklan GG adalah pria-pria yang tinggi, bertubuh, kekar, gagah, tegap, singkatnya tubuh-tubuh yang merepresentasikan maskulinitas yang selama ini terkonstruksi di masyarakat. Representasi ini sulit dipisahkan dari tujuan GG yang tentunya ingin mendominasi pasar Indonesia dengan produkproduknya. Dengan selalu menampilkan sosok-sosok pria yang dianggap ideal, GG berharap bisa menghegemoni para 
audien pria, sehingga tetap memilih produk-produknya. Dengan menganalisa bentuk fisik, sekaligus juga akan dianalisa sifat-sifat yang mungkin melekat, seperti pada tubuh pria-pria dalam beberapa iklan berikut.
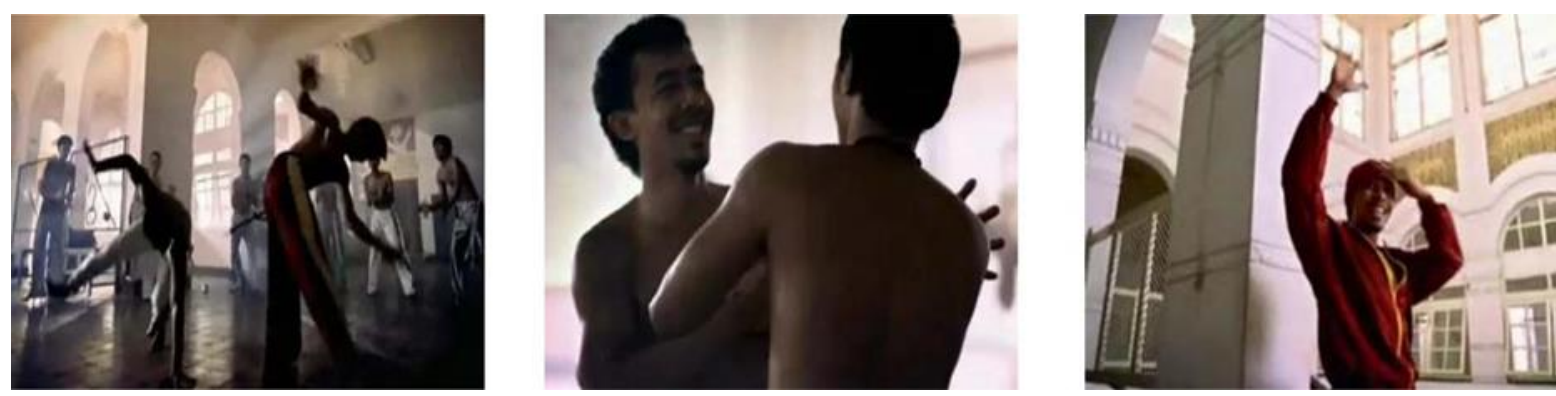

Gambar 1. Berlatih Capoera

Gambar 1 adalah cuplikan dari iklan GG versi Capoera. Kedua pria tersebut adalah capoeirista, mereka terlihat sedang berjabat tangan, atau lebih tepatnya gerakan khas dalam bela diri capoera yang dilakukan setiap mengakhiri latihan tanding dengan rekan tandingnya. Secara fisik, bentuk tubuh keduanya biasa saja sebagaimana lazimnya bentuk tubuh orang Indonesia. Tidak besar dan juga tidak terlalu kecil, namun telihat proporsional (atletis), kuat dan kekar. Dengan warna kulit sawo matangnya semakin menguatkan aura kelaki-lakiannya. Dari keseluruhan tampilan fisiknya yang atletis serta penanda-penanda lainnya, dalam istilah sehari-hari, pria seperti ini biasa disebut pria macho. Kemacho-annya semakin dipertegas dengan aktifitas mereka berlatih beladiri capoera yang sangat identik dengan laki-laki karena sangat mengandalkan kekuatan fisik (khususnya keuatan tangan) dan kelincahan dalam melakukan gerakangerakan akrobatik. Sebuah perpaduan yang sangat identik dengan citra maskulin.

Bila melihat dari bentuk tubuh pria dalam iklan Survivor yang atletis, dan mengacu pada pendapat Kretschmer dan Heymauns maka pria tersebut kemungkinan memiliki sifat-sifat antara lain egoistis dan ingin berkuasa, sombong, optimis, gepassioneer, kholerikus dan flegmatikus. Sifat-sifat ini sejalan dengan faktor sosial yang ditampilkan dalam iklan. Perlu disampaikan bahwa ada tiga faktor penting yang mempengaruhi kepribadian, yaitu: Pertama, faktor biologis, yaitu faktor yang berhubungan dengan keadaan jasmani, atau seringkali disebut sebagai faktor fisiologis. Kedua, faktor sosial, ialah masyarakat; manusia-manusia lain di sekitar individu yang mempengaruhi individu yang bersangkutan. Termasuk ke dalam faktor sosial ini juga tradisi-tradisi, adat-istiadat, peraturan-peraturan, bahasa, dan sebagainya yang berlaku dalam masyarakat tersebut. Ketiga, faktor kebudayaan, faktor ini sejatinya sama dengan faktor sosial.
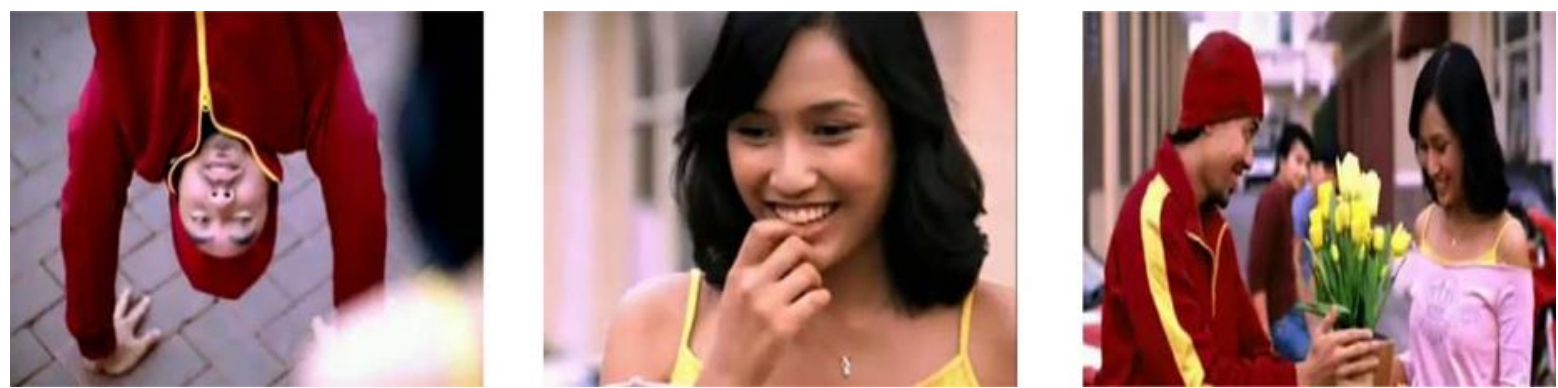

Gambar 2. Menyelamatkan Pot Bunga

Namun dengan latar sosial Indonesia, dimana masyarakatnya masih kental dengan nuansa gotong royong yang penuh kebersamaan, tentunya sifatnya akan menyesuaikan. Pria pada iklan Capoera mempunyai sifat ramah, mudah menyesuaikan diri, cermat, tenang dan sanguinikus (gembira, lincah dan optimis), perayu dan perasa, meskipun egois tentunya dalam makna positif yaitu ingin selalu menjadi yang terbaik/pemenang. Sifat-sifat ini terbukti dengan ekspresi kegembiraan dan keramahannya saat bertemu dan berpisah dengan teman-teman sesama capoeirista. Suasana ini semakin diperkuat oleh latar warna yang didominasi oleh warna-warna cerah seperti merah, putih, kuning, hijau, yang secara psikologis memberikan efek segar, ceria dan energik. Ketenangannya dan kecermatannya terlihat ketika ia 
melakukan berbagai gerakan akrobatik saat menyelamatkan pot bunga. Sifat sentimentilnya bisa dilihat pada akhir tayangan, ia menyerahkan bunga pada si wanita dengan penuh perasaan.

Iklan di atas menujukkan citra maskulinitas tradisional yang mempelihatkan kekuatan, keberanian, dll. Citra maskulinitas tradisional tidak lagi terasa pada iklan The Plane berikut.

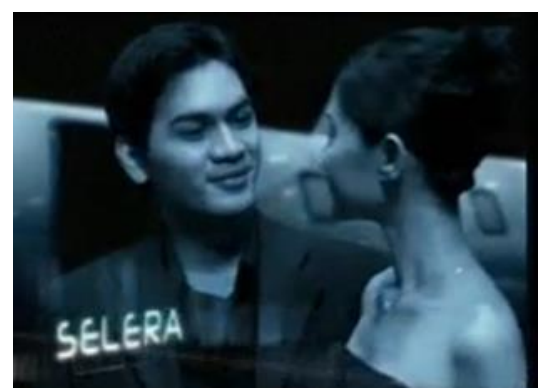

Gambar 3. Dating

Gambar 3 menampilkan pria tampan, berambut rapi, berwajah bersih dan berkulit lembut dan mulus. Secara fisik ia tetap masuk kategori atletis ala Indonesia, tetapi tetap berbeda dengan pria bertipe sama pada iklan Capoera. Ia sama sekali tidak terlihat keras atau powerful, melainkan lebih lembut namun tetap berenergi. Dari penampilan fisik dan kemewahan pakaiannya ia adalah pria metroseksual. Hal ini sejalan dengan tema iklan yang menunjukkan tentang kekayaan dan kemewahan, karena secara umum pria metroseksual adalah pria-pria kaya dan bergaya hidup mewah.

Meskipun bertipe tubuh sama dengan pria iklan Capoera namun karakter fisik mereka sangat berbeda. Sehingga secara otomatis akan mempengaruhi kepribadian masing-masing. Hal ini wajar saja terjadi karena meskipun mungkin dua orang yang berbentuk tubuh sama berbeda dalam kepribadiannya. Dalam kasus semacam ini maka yang paling berperan adalah faktor sosial dan budayanya. Dengan demikian, pria pada iklan The Plane memiliki sifat ramah, mudah menyesuaikan diri, mudah bergaul, terbukti dengan kehadirannya di hotel yang menghadiri sebuah acara. Selain itu, Ia juga bersifat flegmatikus dan sentimentil, atau boleh dimasukan ke dalam salah satu golongan watak manusia menurut Spranger, yaitu sebagai manusia seni, yang bersifat suka menikmati/mengenyam keindahan. Sifat-sifat ini didukung pula latar warna gelap (paduan hitam dan biru) memberi kesan eksklusif, tenang dan damai. Berbeda dengan dua iklan sebelumnya yang cenderung menonjolkan kekuatan fisik, tetapi kali ini yang ditonjolkan adalah kekuatan finansial. Perbedaan sifat dan pergeseran bentuk kekuatan yang ditampilkan sangat sesuai dengan latar tempat, sosial dan budaya. Kita tentu bisa merasakan perbedaan antara jalanan, dan hotel mewah.

Dari kedua iklan di atas, kita telah melihat perbedaan bentuk tubuh dan penampilan yang ternyata mempengaruhi kepribadian masing-masing. Iklan berikut akan menunjukkan penggabungan dari keduanya, baik secara fisik maupun sifat, sebagaimana yang ditampilkan dalam iklan The Bag berikut.
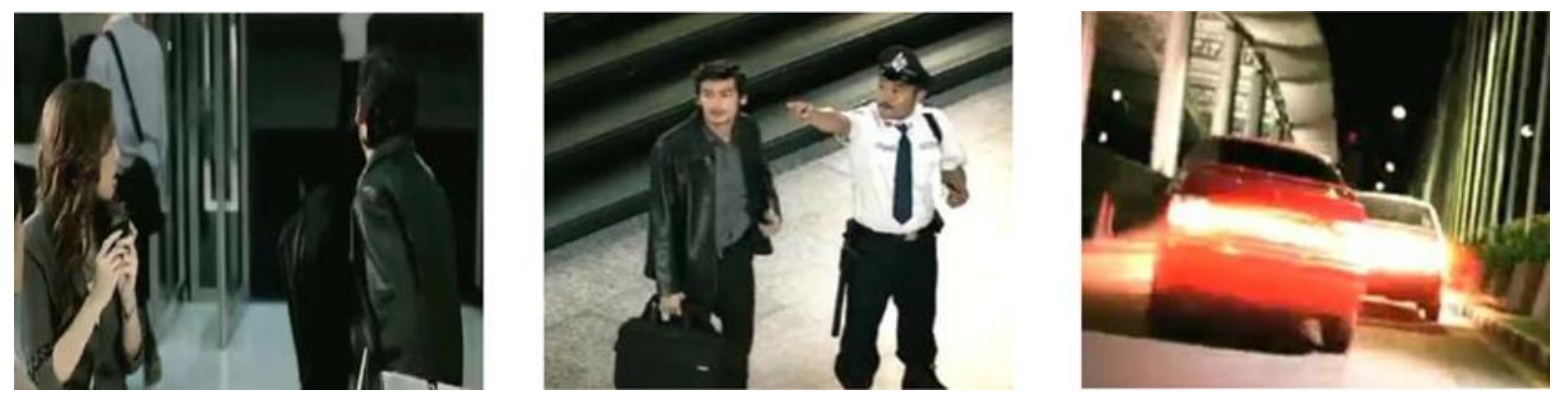

Gambar 4. Mencari Jalan

Secara umum Iklan The Bag ini memiliki kesamaan dengan iklan Capoera yaitu bercerita tentang kehebatan pria dalam menyelesaikan masalah. Secara fisik ia masuk tipe atletis ala Indonesia. Coba bandingkan dengan bentuk tubuh pria disebelahnya yang bertipe piknis. Perbedaan ini menunjukkan adanya dominan dan subordinat. Bila dikaitkan dengan teori Connell, di mana bentuk tubuh piknis dianggap subordinat karena tidak ideal menurut konstruksi 
masyarakat, dan pria ini pun ditampilkan subordinat dari segi pekerjaan, yang berprofesi sebagai Satpam (Satuan Pengamanan).

Penampilan yang lebih rapi, menggunakan kemeja, jaket, celana hitam dan sepatu yang mengkilap menunjukkan ia adalah seorang yang bekerja di kantor. Dari dandanan, ketampanan wajahnya, serta kulitnya yang putih bersih, maka ia sebetulnya bisa dikategorikan sebagai pria metroseksual. Namun hanya sebatas tampilan fisik saja dan bukan esensinya. Bila mengacu pada definisi Chamim dalam Tempo, bahwa metroseksual adalah laki-laki tajir yang hartanya banjir, maka pria dalam iklan The Bag belum sepenuh bisa dikatakan metroseksual meski ia termasuk pria kaya (memiliki pekerjaan dan mobil) karena ia masih ditampilkan bekerja (mencari uang). Sangat berbeda sekali dengan iklan The Plane, di mana prianya ditampilkan menikmati uang (kekayaan).

Walaupun secara fisik dan penampilan ia lebih mirip pria metroseksual, tetapi aksinya dalam iklan memiliki tingkat 'kekerasan dan bahaya'. Dengan demikian ia memiliki sifat yang lebih kompleks, antara lain: lembut, ramah, mudah bergaul dan beradaptasi flegmatikus dan sanguinikus. Di sisi lain, ia juga bersifat, sombong, egois, gepassioneer dan kholerikus, yang terasa sangat dominan saat ia tengah dalam masalah. Selain karena bentuk fisiknya yang memungkinkan ia memilki sifat-sifat tersebut, lagi-lagi faktor sosial sangat berperan di sini. Dengan setting sosial masyarakat urban, dan jenis pekerjaan, memang dituntut untuk memilki sifat lembut, ramah, mudah bergaul dan beradaptasi flegmatikus dan sanguinikus karena mobilitas dan tingkat interaksi dengan orang lain di kota besar lebih tinggi. Di saat yang sama, kota besar juga merupakan arena pertarungan yang kejam dan keras, dimana setiap orang tega melakukan apa saja demi mempertahankan hidupnya, dan situasi ini kadang-kadang memerlukan sifat yang sedikit 'keras'.

Dari penjelasan bentuk-bentuk fisik di atas, tampak bahwa ada pergeseran bentuk tubuh, penampilan, dan juga kepribadian. Secara sosial bentuk fisik pria sering didefinisikan besar, tinggi, gagah, tegap, berotot, dan berdada lebar, yang oleh Kretschmer disebut atletis. Meskipun ketika ditarik ke dalam konteks Indonesia terdapat perubahan cukup mencolok terutama dalam hal ukuran. Pertanyaannya mengapa tubuh atletis menjadi dominan? David Brown telah melakukan penelitian terhadap lima orang pria bertubuh kekar dari berbagai kalangan usia dan tempat fitnes yang berbeda. Dari penelitiannya ia menyimpulkan bahwa tubuh yang kekar adalah simbol dari "power" terutama "male power". Secara sosial kekuatan seakan-akan dapat memberikan jaminan keamanan, perlindungan, setidak-tidaknya bagi laki-laki itu sendiri. Dan para wanita pun mengamini simbol tersebut dengan menyatakan bahwa ada perasaan aman dan bangga berada bersama pria yang kekar penuh kekuatan. Salah seorang responden Brown, bahkan mengatakan dengan bertubuh besar dan kekar, ia merasa seperti pahlawan atau dewa Yunani.

Perubahan bentuk fisik ini juga tidak lepas dari perubahan sosial budaya. Di masa lalu, ketika masyarakat tradisional masih tinggal di hutan dengan berbagai aktifitas seperti berburu, bertani atau berladang yang mengunakan alat-alat seperti cangkul, parang, panah, tombak maka secara fisik harus besar, kuat dan prima. Saat itu Laki-laki adalah pencari nafkah dan pelindung keluarga, sehingga membutuhkan sosok yang kuat agar bisa maksimal memenuhi kebutuhan dan melindungi keluarganya. Selain itu, aktifitas manusianya lebih banyak dilakukan di alam terbuka seperti sawah, hutan, laut, sungai yang sangat riskan dari ancaman binatang buas atau alam (cuaca buruk), maka kekuatan fisik mutlak diperlukan.

Bandingkan dengan Kondisi saat ini yang serba mesin dan komputer. Manusia bekerja di kantor-kantor mewah, bahkan tidak sedikit yang menjalankan bisnis dari ruang kamar tidurnya dengan hanya menggunakan handphone dan laptop yang telah tersambung jaringan internet. Ditambah lagi dengan terciptanya mesin-mesin raksasa yang mampu bekerja lebih cepat dan baik dari tangan manusia. Singkatnya, saat ini, kekuatan fisik manusia tidak lagi terlalu diperlukan, dan yang terpenting adalah modal (finansial) dan kecerdasan/intelejensi (pendidikan). Lihat saja pria pada iklan The Bag, yang bekerja di kantor, ia bekerja hanya dengan menggunakan laptop dan melakukan persentasi. Aktifitas semacam ini tentu tidak terlalu membutuhkan tubuh yang besar dan kekar. Kekuatannya justru terletak pada kecerdasan otaknya. Dalam konteks industrialisasi, justru laki-laki yang bertubuh kekar dan berotot, bila ia tidak memiliki modal finansial dan pendidikan yang cukup, maka ia hanya akan menjadi buruh (laki-laki tersubordinat). Namun demikian, mitos-mitos yang menganggap bahwa tubuh kekar dan berotot sebagai simbol kejantanan pria sejati masih sangat kuat. Sehingga manusia-manusia modern terhegemoni juga dan berlomba-lomba membentuk tubuh di pusat-pusat kebugaran, tetapi bentuk fisik yang diinginkan tidaklah sebesar dan sekekar Rambo.

Secara biologis, umumnya pria-pria Indonesia bertubuh seperti pada iklan-iklan Capoera, The Plane, dan The Bag. Namun mitos bentuk tubuh tertentu sebagai simbol maskulinitas cukup kuat di masyarakat. Sehingga kesimpulan Brown relevan juga dalam konteks Indonesia, meski 'kekekaran' dalam penelitian Brown sangat berbeda definisinya dengan kekekaran dalam konteks Indonesia. Hal ini terbukti dengan banyaknya pria-pria yang membanjiri pusat-pusat kebugaran, yang juga semakin menjamur mulai dari kota hingga ke desa-desa. Mereka berlomba-lomba membentuk fisik sedemikian rupa agar memenuhi standarisasi sosial. 
Munculnya tipe pria metroseksual pada iklan The Plane ingin mengingatkan bahwa konsep maskulinitas tidaklah tunggal. Maskulinitas tidak selalu diukur dari sisi ke-macho-an yang identik dengan bentuk tubuh dan kekuatan fisik. Demikian juga seperti tubuh pria dalam iklan The Bag. Setting tempat pun mulai bergeser, tidak lagi di jalanan, melainkan hotel atau kantor. Hal yang ditekankan adalah kekuatan finansial dan intelejensi dalam bekerja. Bergesernya masalah bentuk fisik ini juga terjadi dalam masyarakat. Misalnya, sebagian besar wanita menyenangi perut pria yang rata. Beberapa wanita tidak menginginkan perut yang berotot, tetapi perut yang rata lebih baik. Namun tidak bisa dielakkan bahwa konsep maskulinitas tradisional tetap mendominasi, sehingga meski secara representasi penampilan berubah, tetapi tetap memiliki esensi 'kekuatan' yang merupakan ciri khas maskulinitas. Dan GG berusaha tetap memposisikan dirinya pada konsep maskulinitas.

Penjelasan di atas menunjukkan perubahan maskulinitas dalam iklan-iklan GG sangat dipengaruhi oleh perubahan kondisi sosial. Iklan Capoera kental dengan ideologi patriarki, yang menekankan pada aspek kekuatan jasmani dan rohani. Dengan masuknya kepentingan kapitalis, perubahan sangat signifikan muncul pada iklan The Plane dan The Bag, yang menampilkan pria dari kelas menegah atas. Dua iklan sebelumnya tidak terlalu jelas dari kelas sosial yan mana, karena hanya kekuatan fisiknya yang dominan. Kemunculannya pria kalangan atas pada iklan terakhir membuktikan bahwa kapitalisme telah bermain. Mereka tidak lagi tampil dengan kekuatan fisik, melainkan dengan kekuatan finansial dan intelektual. Kapitalis rupanya sangat mengerti benar bahwa kalangan pria iklan The Plane dan The Bag yang mempunyai kemampuan lebih untuk mengkonsumsi, sehingga dengan menampilkan mereka, sejatinya kapitalis sedang membidik masyarakat kalangan atas. Perubahan ini dimunculkan oleh GG karena GG sendiri melihat kecederungan iklan-iklan produk-produk lainnya, yang selalu menampilkan kelas atas. Jadi, secara umum iklan tidak semata-mata ingin memperkenalkan produknya saja, tetapi lebih pada penanaman sikap konsumtif, jika sikap ini sudah tertanam maka yang paling diuntungkan adalah para kapitalis secara keseluruhan. Konsumerisme ini akan semakin terasa pada bagian selanjutnya, ketika membahas masalah sombol-simbol kekayaan. Akhirnya, dari keempat iklan tersebut ternyata memiliki kesamaan yaitu para pria yang bertipe tubuh atletis, khususnya atletis ala Indonesia. Ini menunjukkan bahwa esensi maskulinitas tradisional, yaitu 'kekuatan' masih tetap kuat menghegemoni, yang dulunya kekuatan fisik, bergeser pada kekuatan otak dan finansial. Kata kuncinya tetaplah 'kekuatan', dan kekuatan inilah nilai yang selalu dipertahankan dalam budaya patriaki.

\section{Materi (Kekayaan)}

Kekayaan memiliki peran cukup dalam persoalan dominasi atau hegemoni. Dimensi kekayaan seseorang sangat mempengaruhi stratifikasi sosial seseorang di masyarakat. Stratifikasi sosial menjadi penting untuk dibahas karena perbedaan lapisan sosial inilah penyebab utama terjadinya dominasi. Misalnya lapisan atas cenderung akan mendominasi lapisan di bawahnya. Stratifikasi sosial muncul akibat ada gejala di mana masyarakat memiliki penghargaan tertentu terhadap hal-hal tertentu dalam masyarakat yang bersangkutan, yakni pembedaan posisi seseorang atau suatu kelompok dalam kedudukan yang berbeda-beda secara vertikal. Menurut Soerjono Soekanto, dalam setiap masyarakat selalu mempunyai sesuatu yang dihargai. Sesuatu itu adalah dapat berupa kekayaan, ilmu pengetahuan, status kebangsawanan, kekuasaan, atau hal-hal yang bersifat ekonomis.

Setidaknya ada tiga hal yang menyebabkan seseorang bisa masuk dalam stratifikasi sosial tertentu, yaitu kekayaan (penghasilan), pekerjaan, dan pendidikan. Berdasarkan pertimbangan inilah iklan-iklan GG, dalam setiap tampilan sangat identik dengan ketiga hal tersebut. Hal ini mungkin ingin menegaskan bahwa GG adalah salah satu perusahaan rokok terbesar di Indonesia, yang tentunya juga untuk kelas-kelas sosial tertentu (baca: kelas atas). Meski demikian GG juga punya produk yang khusus ditujukan untuk kalangan bawah, seperti Gudang Garam Merah, yang terbukti pada setiap tampilannya tidak merepresentasikan golongan atas. Tetapi secara umum, dapat dikatakan GG merepresentasikan golongan menengah dan atas. Tidak mengherankan jika iklan-iklan GG sering menampilkan visualisasi berupa mobil, hotel mewah, eksekutif muda, wanita cantik, atau hal-hal yang berrelasi dengan kekayaan, seperti pada salah satu iklan GG berikut yang menampilkan tentang pekerjaan. 

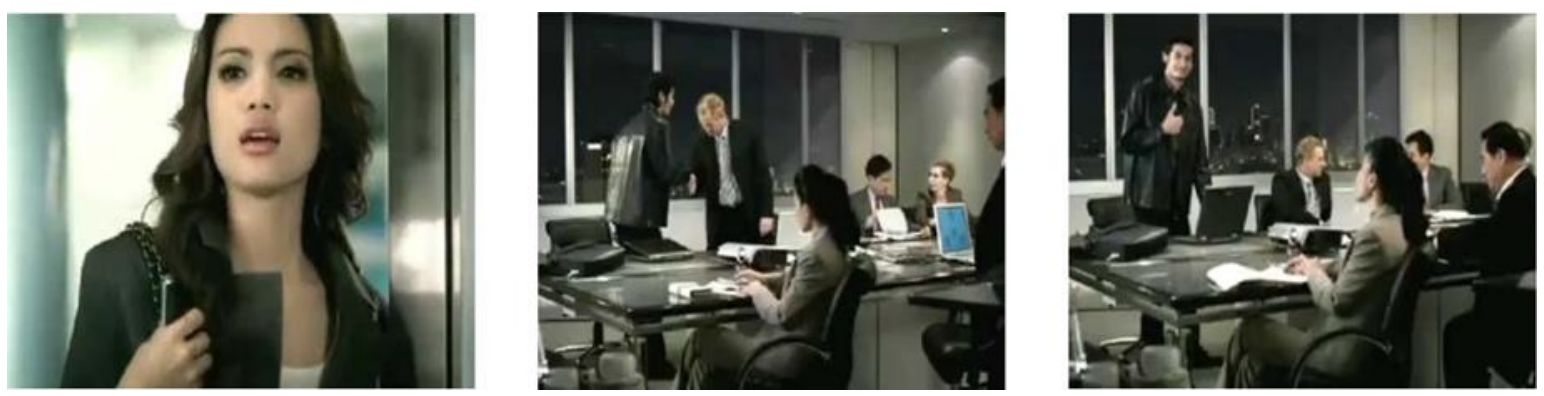

Gambar 5. Presentasi

Gambar di atas adalah cuplikan iklan versi The Bag. Cuplikan tersebut memperlihatkan sebuah ruangan kantor, sepertinya meeting room, yang cukup mewah. Seorang pria yang sedang berjabat tangan dengan seorang ekspatriat. Dalam ruangan tersebut terdapat tiga orang ekspatriat, tiga orang pribumi, termasuk si pria tadi. Kantor tersebut adalah kantor klien si pria, ia datang untuk melakukan presentasi. Dari visualisasi ini, bisa disimpulkan bahwa sang pria pasti memiliki pekerjaan dan peran penting kantornya.

Dalam iklan ini, si pria memang direpresentasikan sebagai sosok yang penting. Hal itu semakin diperkuat dengan visualisasi di atas, ketika berjabat tangan dengan seorang ekspatriat yang merupakan kliennya, kliennya terlihat sangat menghormati, dengan membungkukkan badan lebih rendah dari si pria. Dalam konteks Indonesia, keberadaan ekspatriat dalam sebuah kantor pasti memiliki peran penting (biasanya sebagai pimpinan atau tenaga ahli). Kita cenderung menganggap para ekspatriat lebih baik dalam segala hal. Pandangan ini disebabkan oleh semacam sindrom poskolonial, dimana definisi poskolonial sering dihubungkan dengan proses konstruksi budaya menuju budaya "putih global". Kebudayaan kulit putih dipandang sebagai acuan perkembangan bagi semua budaya. Bahkan proses seperti ini tetap berlangsung ketika penguasaan kulit putih atas sebuah negara berakhir.

GG mencoba mengacak common sense ini dengan menampilkan sosok ekspatriat yang justru terlihat subordinat dengan membungkukkan badan lebih rendah dari si pria. Ini merupakan kritikan cerdas atas dominasi negara-negara dunia pertama selama ini. Hal ini sengaja dilakukan GG untuk memberi citra bahwa si pria dalam iklannya adalah seseorang yang berkelas yang pantas dihormati. Sikap si ekspatriat yang demikian bisa terjadi karena dua hal; karena si ekspatriat tersebut adalah seorang yang low profile, atau mereka memiliki jabatan yang sama. Kemungkinan yang logis adalah yang kedua; jabatan mereka setara. Meskipun demikian, bila mengacu pada common sense, kesetaraan ini saja sudah berarti kemenangan bagi si pria Indonesia.

Selain menjadi sosok yang penting, si pria tersebut juga ditampilkan sebagai sosok yang cerdas. Kecerdasannya (intelligence) dibuktikan dengan tugasnya untuk melakukan presentasi. Tidak semua orang (meski dengan tingkat pendidikan tinggi) bisa melakukan presentasi. Selain harus memiliki pengetahuan dan wawasan yang luas tentang hal yang akan dipresentasikan, seorang presenter haruslah memiliki kemampuan komunikasi yang baik. Kemampuan komunikasi inilah yang jarang dimiliki setiap orang. Namun bila melihat cerita dalam iklan yang menampilkan si pria menghadapi beberapa masalah besar dan ia mampu mengatasinya, maka intelektual yang dimaksud tidak sepenuhnya IQ, melainkan kecerdasan emosional (Emotional Intelligence). Kecerdasan emosional adalah kemampuan untuk memotivasi diri dan bertahan menghadapi frustrasi; mengendalikan dorongan hati dan tidak melebih-lebihkan kesenangan; mengatur suasana hati dan menjaga agar beban stres tidak melumpuhkan kemampuan berfikir; berempati dan berdoa.

Menurut Goleman, IQ hanya menyumbang kira-kira 20 persen bagi faktor-faktor yang menentukan dalam hidup, maka yang 80 persen diisi oleh kekuatan-kekuatan lain. Dalam Iklan ini diceritakan bahwa si pria akan melakukan presentasi. Tiba-tiba ketika di lobi tas, laptop-nya tertukar dengan orang lain, sementara waktu presentasi tinggal 20 menit lagi. Namun pria tersebut tetap bisa menguasai diri dan tenang, ia lantas mengejar pria yang membawa tasnya. Meski dalam keadaan macet, ia tetap tidak kehilangan akal. Bahkan ia menunjukkan kemampuan akrobatiknya saat menyalip sebuah mobil dengan cara memiringkan mobilnya, ia hanya menggunakan dua roda saja. Ia berhasil melawati semua masalah tersebut dan bisa melakukan presentasi tepat waktu. Keberhasilan ini menujukkan kecerdasan emosional si pria yang mampu memotivasi diri dan tidak frustrasi saat menghadapi masalah besar.

Titik tekan bagian ini adalah masalah kekayaan. Salah satu unsur dalam stratifikasi sosial adalah status (kedudukan). Menurut Pitirim Sorokin, untuk mengukur status seseorang bisa dilihat dari: Jabatan atau pekerjaan, pendidikan, kekayaan, politis, keturunan dan agama. Dari cara memperolehnya, status sering dibedakan menjadi dua; Ascribedsatatus (status keturunan) dan Achieved-status, status yang didapatkan melalui usaha-usaha yang sengaja dilakukan, 
bukan atas dasar kelahiran. Kekayaan adalah satu unsur status, dan bila kita mempersamakan cara memperolehnya, maka kekayaan pun didapatkan melalui dua cara yaitu dari warisan orang tua (ascribed) dan bekerja (achieved). Pekerjaan itu sendiri sangat ditentukan oleh tingkat pendidikan. Terlihat di sini betapa banyak hal yang saling berkelitkelindan dan mempengaruhi. Namun intinya tetap satu yaitu tentang 'status sosial' tertentu.

Selain dari jenis pekerjaan, kekayaan sering disimbolkan dengan kepemilikan barang-barang. Simbolisme atau lambang-lambang adalah sangat penting dalam masyarakat dan kehidupan. Kekuasaan dan otoritas politik memiliki simbol-simbol tertentu. Dalam tradisi Jawa simbol kekuasaan adalah payung kuning (emas), pola batik parang rusak yang hanya boleh dipakai oleh orang "Dalem" (kraton). Dengan demikian para konglomerat yang memiliki kekuasaan uang akan menunjukkan simbol legitimasinya dengan mengendarai/memiliki mobil-mobil mewah hingga pesawat. Mobil adalah simbol status sosial bagi pemiliknya karena kepemilikan mobil (atau barang, jenis aktifitas, gaya hidup) biasanya berbanding lurus dengan kemampuan finansial. Kekayaan maskulinitas dalam iklan GG direpresentasikan dengan kepemilikan kendaraan mewah, seperti pada cuplikan iklan The Plane dibawah ini.
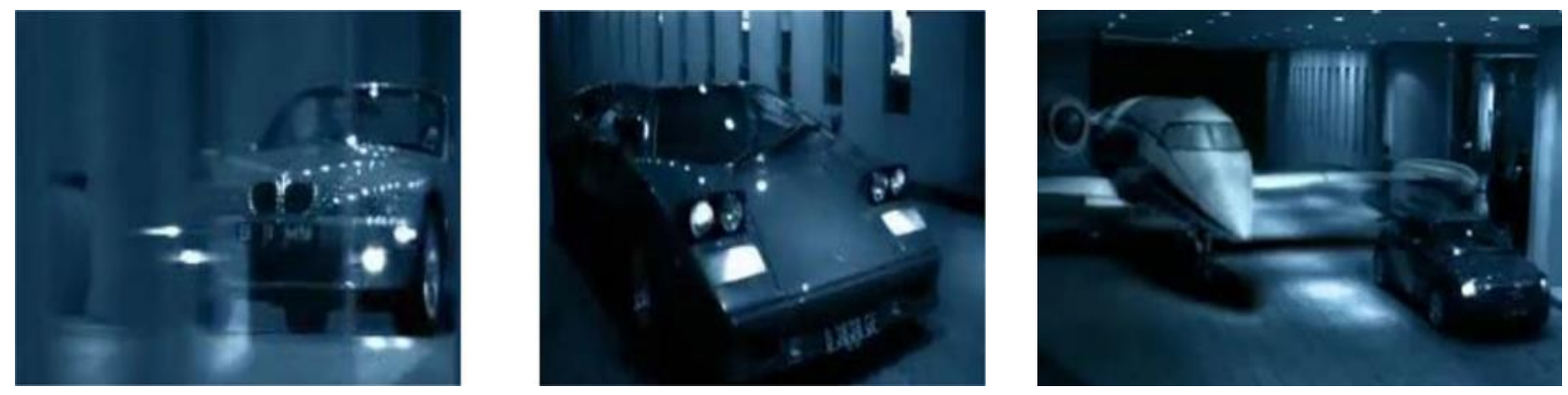

Gambar 6. Kendaraan Mewah

Gambar 6 di atas adalah cuplikan iklan versi The Plane. Iklan ini tentang seorang wanita yang sedang menunggu kekasihnya di lobi sebuah hotel berbintang, sepertinya mereka akan menghadiri sebuah pesta. Setelah sekian lama menunggu rupanya pria yang ditunggu tak kunjung datang. Dua orang pria datang dengan masing-masing menggunakan mobil mewah, tetapi bukanlah kekasihnya. Setelah beberapa saat tampak sebuah pesawat datang, ternyata pria yang menggunakan pesawat itu adalah kekasih si wanita tadi. Dalam iklan ini GG tidak terlalu ada pesan lain, selain hanya menunjukkan kepemilikan kendaraan mewah sebagai simbol kekayaan.

Iklan ini menampilkan dua jenis kendaraan yaitu mobil dan pesawat. Sebuah mobil merek BMW, salah satu merek mobil mewah terkenal. Mobil yang lain tidak hanya mewah tetapi juga canggih. Kecanggihanya terlihat dari bentuknya yang sangat futuristik dan sistem operasinya. Misalnya sistem lampunya, berbeda dengan mobil sebelumnya. Mobil ini memiliki lampu yang bisa terbuka dan tertutup secara otomatis dengan menekan sebuah tombol tertentu. Kemudian cara membuka pintunya berbeda dari mobil-mobil pada umumnya yaitu dengan mendorongnya ke samping kiri atau kanan. Pintu mobil ini terbuka ke atas secara otomatis dengan hanya menekan tombol tertentu. Warna kedua mobil dalam iklan ini tidak terlalu jelas (mungkin silver dan ungu) karena berada dalam temaram cahaya berwarna hitam kebiru-biruan. Namun yang pasti, efek psikologis yang ditimbulkan dari perpaduan antara warna asli mobil dan temaram cahaya memberikan kesan mewah dan eksklusif. Gambar berikutnya menampilkan sebuah pesawat berwarna putih. Dari ukuran dan bentuknya sepertinya bukan jenis pesawat komersil melainkan pesawat pribadi.

Kemunculan pria dengan menggunakan pesawat memang tidak logis karena tidak mungkin sebuah pesawat memasuki sebuah hotel. Iklan ini hanya ingin menunjukkan pria yang memiliki kekayaan yang nyaris tak terbatas. Sedikitpun tidak ditampilkan tentang intelektualitas atau aktifitas/pekerjaan. Tiba-tiba saja muncul pria-pria dengan menggunakan mobil super mewah dan canggih. Pria-pria dengan mobil tersebut tentunya adalah pria dari golongan the highest class. Lalu kita bisa membayangkan pria yang datang menggunakan pesawat tersebut sebagai pria dari golongan the highest of the highest class. Dalam iklan The Bag juga terdapat mobil, tetapi fungsinya agak sedikit berbeda. Mobil pada iklan The Bag merupakan hal yang logis dimiliki karena pekerjaan seseorang dan berfungsi untuk mobilitas bekerja. Sementara pada iklan The Plane, mobil/pesawat berfungsi untuk memamerkan kekayaan.

Selain berfungsi sebagai alat transportasi, jelas mobil memiliki fungsi sosial sebagai simbol kesuksesan. Pesawat, mungkin adalah alat transportasi yang paling mewah dan canggih bagi sebagian besar masyarakat Indonesia. Dengan menumpang pesawat komersil kelas ekonomi saja telah memberi kita simbol status sosial tertentu, setidaknya, agak jauh di atas pengguna bus, metromini atau bajai. Di Indonesia kendaraan yang paling banyak adalah sepeda motor, yang mencapai 75 persen dari total keseluruhan moda kendaraan bermesin termasuk roda empat dan angkutan umum. 
Artinya, secara umum masyarakat Indonesia baru mampu untuk membeli sepeda motor. Kendaraan jenis mobil saja sudah termasuk barang mewah, terlebih jika berbicara pesawat, tentu sesuatu yang luar biasa dan tidak semua masyarakat mampu/pernah menggunakan pesawat. Sehingga bila ada orang yang memiliki pesawat di Indonesia, maka ia adalah orang yang luar biasa secara finansial.

Simbol yang melekat pada kendaraan, diam-diam menyelinap dalam kehidupan sehari-hari. Masyarakat bawah dan menengah berusaha untuk bisa memiliki mobil (tanpa memperdulikan merek dan harga), karena ada semacam pemikiran "yang penting memiliki mobil". Dengan memiliki mobil maka mereka merasa sedikit berbeda dengan orangorang yang selama ini berlevel sama. Mobil biasanya menjadi ukuran untuk dikatakan telah sukses atau belum. Di kalangan atas, kondisinya jauh lebih 'mengerikan'. Mereka tidak lagi pada pandangan "asal memiliki mobil", tetapi berganti-ganti mobil, memburu merek terkenal dan seri-seri terbaru. Ada semacam kepuasan ketika bisa menjadi orang pertama atau satu-satunya yang memiliki mobil dengan jenis tertentu.

Berdasarkan uraian di atas, GG mendefinisikan laki-laki dominan adalah sebagai sosok yang kaya; memiliki pekerjaan, kecerdasan, dan barang (kendaraan). Kekayaan dianggap sebagi salah satu indikator seseorang untuk menempati strata sosial teratas, dan dengan menempati strata sosial atas maka dimungkinkan untuk melakukan dominasi. Pekerjaan (bekerja) masih menjadi cara terpopuler untuk mencapai kekayaan. Semua ini disebabkan kuatnya ideologi kapitalisme dan konsumerisme dalam masyarakat. Kapitalisme sengaja menciptakan citra-citra tertentu, dan pada saat yang sama ia menciptakan barang-barang tertentu sebagai simbol kekayaan, di mana ketika seseorang membeli sebuah barang maka ia akan mendapatkan citra tertentu, misalnya citra sebagai orang kaya, atau sebagai manusia modern. Pada bagian sebelumnya dikatakan bahwa perubahan bentuk fisik (penampilan) dipengaruhi oleh kepentingan kapitalis. Pada bagian ini semuanya terbukti, lihat saja penampilan pria dalam iklan Capoera, iklan ini hanya menampilkan kekuatan fisik saja. Sangat berbeda dengan iklan The plane dan The Bag yang menampilkan mobil, pakaian, pekerjaan, hotel, pesawat, yang sangat identik dengan tindakan konsumtif. GG menampilkan kelompok pria kalangan atas (eksekutif muda dan metroseksual), karena kalangan ini adalah target pasar mereka. Selain itu, GG sendiri merupakan bagian dari sistem kapitalis yang tentunya hanya akan melakukan sesuatu yang sejalan dengan kepentingan kapitalis Barat. Kapitalis tidak lagi memperdulikan adanya kesenjangan sosial atau kecemburuan kelompok bawah. Mereka terus saja memborbardir masyarakat dengan iklan-iklan. Menjadi sangat logis, meski di tengah kondisi masyarakat yang serba sulit, GG tetap menampilkan simbol-simbol kemewahan. Ini sekali lagi membuktikan kekuasaan kapitalis yang luar biasa, ia seolah bebas melakukan apa saja tanpa perlu merasa peduli dengan keadaan.

\section{Simpulan}

Persoalan gender beserta kompleksitasnya mungkin tidak akan pernah selesai dan akan terus bergerak bersama zaman. Selama ini seksisme yang terjadi dalam masyarakat kita dianggap sebagai sesuatu yang given, tanpa pernah tahu alasan mengapa semuanya bisa terjadi? Persoalannya menjadi semakin serius ketika termediasi media. Media (baca: iklan) memotret semua fenomena dalam masyarakat, termasuk persoalan kontestasi antara maskulinitas dan feminitas. Iklan seakan-akan menjadi legitimasi konstruksi gender yang selama ini eksis di masyarakat. Disadari atau tidak, maskulinitas masih tetap mendominasi.

Dari analisis mendalam terhadap beberapa iklan rokok di televisi menunjukkan bahwa: Pertama, maskulinitas hegemonik dalam iklan-iklan GG direpresentasikan dalam dengan menunjukkan masalah ketubuhan dan kepribadian serta materi (kekayaan) yang mencakup pekerjaan dan kepemilikan benda. Maskulinitas mengalami perubahan yang sangat dinamis. Secara tampilan fisik maupun non fisik (kepribadian), kita bisa melihat pergeserannya dari waktu ke waktu. Misalnya, dalam iklan Capoera yang menampilkan pria yang secara fisik tidak kekar, keras dan macho. Tampilan yang sangat kontras terlihat pada iklan The Plane yang menampilkan sosok pria metroseksual yang berkepribadian lebih feminin. Sementara pada iklan The Bag, secara tampilan fisik dapat dikategorikan sebagai metroseksual, namun memiliki sifat yang hampir sama dengan pria pada iklan Capoera. Dari berbagai representasi tersebut, yang paling dominan masih tetap nilai-nilai yang terkandung dalam maskulinitas tradisional. Namun demikian telah ada usaha untuk merubah maskulinitas dengan menampilkan sosok metroseksual. Usaha ini hanya berhasil mengutak-atik maskulinitas dari sisi tampilan fisik saja. Sementara secara esensial tidak berubah, tetap merepresentasikan maskulinitas tradisional. Esensinya adalah 'kekuatan', yang mewujud dalam kekuatan fisik, materi, kecerdasan, mental, kekuatan-kekuatan inilah yang menjadikannya dominan dalam banyak hal.

Secara sederhana, iklan GG tersebut merepresentasikan dua jenis pria, yaitu representasi pria macho (iklan Capoera) dan pria metroseksual (iklan The Plane dan The Bag). Pergeseran representasi dari macho ke metroseksual disebabkan oleh kekuatan kapitalisme yang menyebarkan ideologi konsumerisme. Budaya patriarki yang selama ini identik dengan kekuatan fisik, mental dan penampilan yang maskulin, akhirnya bernegosiasi dengan kondisi sosial yang 
berwajah konsumerisme. Maskulinitas tradisional tak berdaya ketika tubuhnya dipermak menjadi lebih feminin, mengikuti model yang diciptakan oleh kapitalisme, namun demikian ia tetap menyelipkan spirit 'kekuatan' meski itu pun harus berubah dalam bentuk finansial dan kecerdasan.

\section{References}

Barker, Chris. Cultural Studies: Teori dan Praktik, Terj. Nurhadi. Yogyakarta: Kreasi Wacana, 2008.

Billman, Brett N. The Enfleshment of Masculinity(s): The Maintenance of Hegemonic Masculinity, dalam Universitas Volume 2, issue 2 (fall 2006) ISSN 1558-8769.

Brown, David. Male Bodybuilders and The Social Meaning of Muscle, dalam Auto/Biography, Vol. VII, Numbers $1 \& 2$, printed in Great Britain, 1999.

Charlebois, Justin. Cross-Cultural Representations of Hegemonic Masculinity in Shall we Dance, dalam Journal of Intercultural Communication, ISSN 1404-1634, issued 19 Januari 2009.

Crystal, David. The Cambridge Encyclopedia. New York: Cambridge University Press, 1991.

Connell, R.W. An iron Man: The body and some contradictions of hegemonic masculinity. In sport, men and the gender order, edited by M. Messner and D. Sabo. Champaign, IL: Human Kinetic Books, 1990 Masculinities. Los Angeles: University of California Press, 1995.

Demetriou, D.Z. Connell's Concept of Hegemonic Masculinity: A critique. Theory and Society, 2001.

Fakih, Mansour. Analisis Gender dan Transformasi Sosial. Yogyakarta: Pustaka Pelajar, 1996.

Goleman, Daniel. Emotional Intelligence, Jakarta: PT Gramedia Pustaka Utama, 2009.

Hall, Stuart. The Work of Representation, dalam Stuart Hall (ed.), Representation, Cultural Representations and Signifying Practice, SAGE Publication and The Open University, 1997.

Onghokham, "Show" Kemewahan, Suatu Simbol Sukses, dalam Lifestyle Ecstasy: Kebudayaan Pop dalam Masyarakat Komoditas Indonesia (Ed. Idi Subandy Ibrahim), Yogyakarta: Jalasutra, 1997.

Purwanto, M. Ngalim. Psikologi Pendidikan (cetakan keduapuluhtiga), Bandung: P.T. Remaja Rosdakarya, 2007.

Sianipar, Gading. Mendefinisikan Pascakolonialisme?, dalam Hermeneutika Pascakolonial (ed. Mudji Sutrisno \& Hendar Putranto), Yogyakarta: Kanisius, 2004.

Syarbaini, Syahrial dan Rusdiyanta, Dasar-Dasar Sosiologi, Yogyakarta: Garaha Ilmu, 2009. 